Article

\title{
Quantification of Tyrosine in Pharmaceuticals with the New Biosensor Based on Laccase-Modified Polypyrrole Polymeric Thin Film
}

\author{
Ancuța Dinu (D) and Constantin Apetrei *(D)
}

check for

updates

Citation: Dinu, A.; Apetrei, C.

Quantification of Tyrosine in

Pharmaceuticals with the New

Biosensor Based on Laccase-Modified

Polypyrrole Polymeric Thin Film.

Polymers 2022, 14, 441. https://

doi.org/10.3390/polym14030441

Academic Editors: Michał Dudek,

Michał Czerwiński

and Karol Stasiewicz

Received: 30 December 2021

Accepted: 21 January 2022

Published: 22 January 2022

Publisher's Note: MDPI stays neutral with regard to jurisdictional claims in published maps and institutional affiliations.

Copyright: (C) 2022 by the authors. Licensee MDPI, Basel, Switzerland. This article is an open access article distributed under the terms and conditions of the Creative Commons Attribution (CC BY) license (https:// creativecommons.org/licenses/by/ $4.0 /)$.
Department of Chemistry, Physics and Environment, Faculty of Sciences and Environment, "Dunărea de Jos" University of Galati, 47 Domnească Street, RO-800008 Galati, Romania; ancuta.dinu@ugal.ro

* Correspondence: apetreic@ugal.ro; Tel.: +40-727-580-914

\begin{abstract}
Stress, a state of body tension, sometimes caused by increased levels of tyrosine (Tyr) in the body, can lead to serious illnesses such as depression, irritability, anxiety, damage to the thyroid gland, and insomnia. The body can be provided with an adequate concentration of tyrosine by taking pharmaceutical products or by dietary intake. Therefore, this study presents the development of a new enzyme sensor for the quantification of Tyr in pharmaceuticals. A screen-printed carbon electrode (SPCE) was modified with the conductive polymer (CP) polypyrrole (PPy) doped with hexacyanoferrate (II) anion ( $\mathrm{FeCN}$ ), the polymer having been selected for its excellent properties, namely, permeability, conductivity, and stability. The enzyme laccase (Lacc) was subsequently immobilized in the polymer matrix and cross-linked with glutaraldehyde, as this enzyme is a thermostable catalyst, greatly improving the performance of the biosensor. The electrochemical method of analysis of the new device, Lacc/PPy/FeCN/SPCE, was cyclic voltammetry (CV), and chronoamperometry (CA) contributed to the study of changes in the biosensor with doped PPy. $\mathrm{CV}$ measurements confirmed that the Lacc/PPy/FeCN/SPCE biosensor is a sensitive and efficient platform for Tyr detection. Thus, this enzyme sensor showed a very low limit of detection (LOD) of $2.29 \times 10^{-8} \mathrm{M}$, a limit of quantification (LOQ) of $7.63 \times 10^{-8} \mathrm{M}$, and a very high sensitivity compared to both devices reported in the literature and the PPy/FeCN/SPCE sensor. Quantitative determination in pharmaceuticals was performed in L-Tyr solution of different concentrations ranging from 0.09 to $7 \times 10^{-6} \mathrm{M}$. Validation of the device was performed by infrared spectrometry (FT-IR) on three pharmaceuticals from different manufacturers and with different Tyr concentrations.
\end{abstract}

Keywords: biosensor; tyrosine; laccase; polypyrrole; cyclic voltammetry; hexacyanoferrate

\section{Introduction}

Electrochemical biosensors, designated by scientific researchers as modern analytical devices for the detection of various organic or inorganic compounds, facilitate the performance of many activities in everyday life, activities that require financial efforts, time, and inefficiency [1,2]. Thus, the objective of this paper is to develop an enzyme sensor for the detection of the amino acid (AA) L-Tyr in pharmaceuticals by the cyclic voltammetry (CV) method. The detection of L-Tyr in pharmaceuticals is of great importance for the quality control of pharmaceutical products, in the monitoring of the stability of the pharmaceuticals during storage, and in studies regarding interaction with other active compounds or excipients. Furthermore, knowing the concentration of L-Tyr in a pharmaceutical product can provide accurate information about the bioavailability of the drug in the body and the amount of active substance in relation to the rate at which it is absorbed into the body. The essence of a biosensor is to convert the biological response into an electrical signal, and to manufacture it, materials such as enzymes, antibodies, and nucleic acids are used, which requires multidisciplinary research in chemistry, medicine, pharmacy, biology, and engineering $[3,4]$. 
One of the reasons for the present investigation is stress, which is an unavoidable part of human existence and which can take extreme forms, causing numerous mental disorders such as depression, anxiety, schizophrenia, post-traumatic stress disorder, sleep disorders, and thyroid disorders [5-7].

This L-Tyrosine is hydrophobic, non-polar, and has a phenolic hydroxyl group, which gives it a distinctive reactivity, as shown in Figure 1 [8].<smiles>N[C@@H](Cc1cccc(O)c1)C(=O)O</smiles>

Figure 1. Chemical structure of the L-Tyrosine isomer.

It has been scientifically proven that Tyr is beneficial in reducing the damaging physical effects of stress hormones and that it has notable contributions in the treatment of mental disorders, especially in lowering the depression level, on the one hand through the administration of pharmaceutical products containing this $\mathrm{AA}$, and on the other hand through dietary intake of foods rich in Tyr, such as fish, meat, eggs, cheese, etc. [9,10]. For the present study, Tyr was selected to be detected from pharmaceutical products, as it is one of the non-essential AAs of the human body that is used to synthesize proteins, and when insufficient amounts are ingested, the body undergoes a series of changes at the level of the central nervous system [11]. Tyr has two isomers: L-Tyr and D-Tyr, synthesized in vivo from the essential AA L-Phe [12]. The WHO stresses a recommended daily intake of Tyr and Phe of $25 \mathrm{mg} / \mathrm{kg}$ body weight [13], showing that an increased level of Tyr can lead to fits of depression [14], Parkinson's [15], and emotional disorders, and a low level to phenylketonuria (PKU) [16,17], albinism [18], and alkaptonuria [9]. Tyrosinemia is a hereditary, autosomal recessive disease that consists of the incorrect metabolism of Tyr, affecting the liver, kidneys, and peripheral nerves, and for this reason Tyr is measured in all newborn screening programs [19].

In the paper by Dinu and Apetrei, published in 2021, the PPy/FeCN/SPCE sensor was developed for the detection of L-Tyr in pharmaceuticals, obtaining an LOD of $8.2 \times 10^{-8} \mathrm{M}$ and exhibiting good electroanalytical performance, i.e., fast response and better sensitivity and stability than the sensors developed in the literature [20]. This study continued this research direction, turning the sensor into a biosensor. Thus, in addition to modifying the sensor with FeCN-doped Ppy-conducting polymer, the enzyme Lacc was immobilized using glutaraldehyde, an enzyme studied since the 19th century [21]. There are several enzymes that can be used for the detection of amino acids (AAs), the most common being tyrosinase, but Lacc was selected for this study, as it is easy to use, requiring no co-factors and participating in many oxidation reactions for a wide variety of organic substances (polyamines, polyphenols, diamines, lignins) [22]. In addition, the presence of the enzyme led to a biosensor with much higher performance compared to the previously obtained sensor, i.e., increased stability, conductivity, reproducibility, and sensitivity; easy preparation; and possibility of use at neutral $\mathrm{pH}$.

Over time, a variety of methods have been used for the detection of Tyr, such as chemiluminescence [23], liquid chromatography-mass spectrometry (LC-MS) [24], fluorimetry [25], UV high-performance liquid chromatography (HPLC) [26], and capillary electrophoresis [27], methods that present a series of limitations: expensive equipment, long analysis time, and possibilities of working in a limited concentration range. In this respect, electrochemical methods such as CV [28,29], differential pulse voltammetry (DPV) [30,31], square wave voltammetry (SWV) [32], and linear sweep voltammetry (LSV) [33,34] have 
been developed and applied, with several advantages: a wide linear range of biosensor response, cheap equipment, and high stability [35].

In the present study, three methods were used to develop the biosensor: chronoam perometry-useful in the stage of modifying the electrode with doped PPy, cyclic voltammetry to characterize the electrode performance, and the FT-IR method to validate the results obtained.

The novelty of this work is the quantification of tyrosine in pharmaceutical products by means of a device developed in the laboratory, using a conductive polymer doped with an anionic agent and an enzyme fixed with a cross-linking agent on a screen-printed carbon electrode, which, following electrochemical analysis by the cyclic voltammetry method, obtained increased performance, sensitivity, and selectivity. Currently, there are no studies on tyrosine detection with a PPy- and Lacc-modified enzyme sensor, and future research directions should consider the application of the biosensor on biological fluids.

\section{Materials and Methods}

\subsection{Chemicals and Reagents}

Screen-printed carbon electrodes (SPCE), model DRP-C110, diameter of $4 \mathrm{~mm}$, surface of $12.56 \mathrm{~mm}^{2}$, were purchased from Metrohm DropSens (Oviedo, Spain). The following chemicals were purchased from Sigma-Aldrich (St. Louis, MO, USA): pyrrole (98\%), $\mathrm{FeCN}(\geq 99.5 \%)$, laccase (Lacc), glutaraldehyde (GA), L-Tyr ( $\geq 98 \%$ ), and potassium chloride $(\geq 99.0 \%)(\mathrm{KCl})$. The real samples were represented by products purchased from the pharmaceutical market. Ultrapure water $\left(18.3 \mathrm{M} \Omega \cdot \mathrm{cm}\right.$, Milli-Q Simplicity ${ }^{\circledR}$ Water Purification System from Millipore Corporation-Millipore, Bedford, MA, USA) was used to prepare solutions of these compounds.

\subsection{Instruments and Methods}

The EG\&G potentiostat/galvanostat (Princeton Applied Research, Oak Ridge, TN, USA) $263 \mathrm{~A}$ model, controlled by ECHEM software, was the device used to modify the working electrode with FeCN-doped PPy by the CA method. Three electrodes were connected to this device: the $\mathrm{Ag} / \mathrm{AgCl} / \mathrm{KCl}_{3 \mathrm{M}}$ reference electrode, the platinum (Pt) wire auxiliary electrode, and the SPCE working electrode, simultaneously introduced into the electrochemical cell.

$\mathrm{CV}$, the method used for biosensor characterization, was applied using the Biologic SP 150 potentiostat/galvanostat (Bio-Logic Science Instruments SAS, Seyssinet-Pariset, France) controlled by EC-Lab Express software. In this case, a $15 \mathrm{~mL}$ electrochemical cell was used, in which the three electrodes were immersed: the Lacc/Ppy/FeCN/SPCE working electrode, the reference electrode, and the auxiliary electrode (counter electrodecarbon, $\mathrm{Ag} / \mathrm{AgCl}$ reference electrode). The working parameters of $\mathrm{CV}$ were different scan rates of $0.1-1.0 \mathrm{~V} \cdot \mathrm{s}^{-1}$ and the optimal potential range was between -1.0 and $0.5 \mathrm{~V}$. The analyzed solutions used for the electrochemical studies were $0.1 \mathrm{M} \mathrm{KCl}$ solution and a double solution of $0.1 \mathrm{M} \mathrm{KCl}-10^{-3} \mathrm{M} \mathrm{L}-\mathrm{Tyr}$. The voltammograms obtained were analyzed using two programs: ORIGIN vs. 6.0 Professional and Microsoft Excel.

For biosensor validation, the FT-IR method was applied to the Bruker ALPHA FT-IR spectrophotometer (BrukerOptik GmbH, Ettlingen, Germany) in the range of $4000-500 \mathrm{~cm}^{-1}$, controlled by OPUS software (BrukerOptik GmbH, Ettlingen, Germany).

The Elmasonic S10H device (ultrasonic bath) was used for homogenization and dissolution of solutions.

\subsection{Process for the Preparation of the PPy/FeCN/Lacc/SPCE Enzyme Sensor}

\subsubsection{Preparation of the Monomer/Doping Agent Solution (PPy/FeCN)}

A solution of exact concentration obtained from pyrrole, potassium hexacyanoferrate (II) (FeCN), and $\mathrm{KCl}$ of $0.1 \mathrm{M}$ pyrrole/0.1 M FeCN/0.1 M KCl was used to modify the sensor. To homogenize the three compounds, the flask containing the prepared solution was placed in the ultrasonic bath apparatus for $5 \mathrm{~min}$. The deposition was achieved by connecting 
the DRP-C110 sensor to the electrochemical cell and introducing the three electrodes into the monomer/doping-agent solution, applying a potential of $0.8 \mathrm{~V}$ for $90 \mathrm{~s}$ at a constant temperature of $25^{\circ} \mathrm{C}$. Subsequently, these prepared sensors were rinsed with ultrapure water. The method to characterize the changes occurring on the sensor working surface was chronoamperometry.

\subsubsection{Manufacture of the PPy/FeCN/Lacc/SPCE Biosensor}

The transformation of the PPy/FeCN/SPCE sensor into the PPy/FeCN/Lacc/SPCE biosensor was achieved by droplet pouring the Lacc enzyme onto the working surface of the electrode, equivalent to $10 \mu \mathrm{L}$ enzyme. This stage was followed by cross-linking with glutaraldehyde (GA) reagent and drying. The biosensor preparation technique is also called the drop-and-dry technique. To obtain the laccase solution, $0.05 \mathrm{~g}$ laccase dissolved in $0.1 \mathrm{M} \mathrm{KCl}$ solution was used, of which $2 \mu \mathrm{L}$ was added in five steps to the working surface of the PPy/FeCN-modified electrode and placed on top of $2 \%$ glutaraldehyde vapor for $1 \mathrm{~min}$, a procedure called cross-linking, illustrated in Figure 2. Many researchers have used GA prior to enzyme immobilization because cross-linking decreases the rate of enzyme deactivation, but few have attempted the cross-linking process after enzyme application [36]. Before using the biosensor, it was kept for 5-10 min at room temperature. The prepared biosensors were stored at $4{ }^{\circ} \mathrm{C}$ in darkness until use.
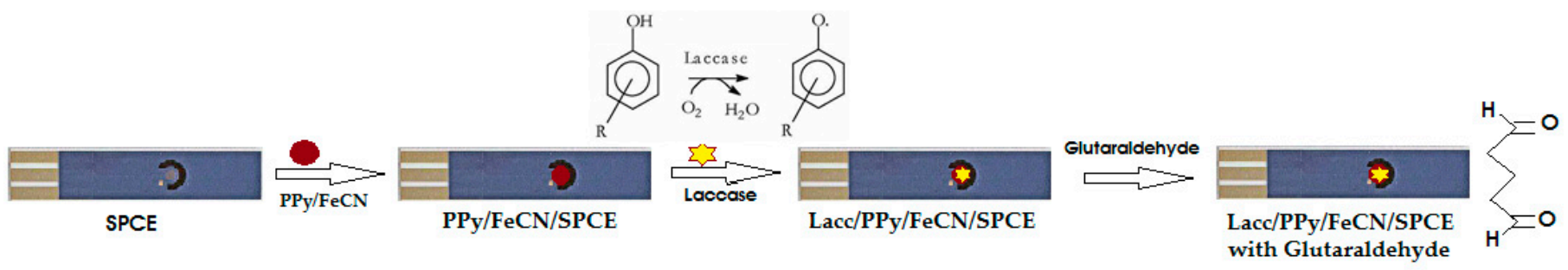

Figure 2. Schematic diagram of the immobilization of the Lacc enzyme in the construction of the biosensor.

The characterization of these biosensors was performed by electrochemical measurements, applying the $\mathrm{CV}$ method, with the following pre-set parameters: initial potential $0.0 \mathrm{~V}$, positive vertex potential $0.5 \mathrm{~V}$, negative vertex potential $-1.0 \mathrm{~V}$, and a scan rate between 0.1 and $1.0 \mathrm{~V} \cdot \mathrm{s}^{-1}$.

\subsection{Analysis of Real Samples}

Three products purchased from the pharmaceutical market from different manufacturers were analyzed. The criteria for the selection of these products were the Tyr content and the different concentrations of Tyr in the pharmaceutical products. Cebrium, manufactured by EVER NEURO PHARMA GmbH Austria, is a dietary supplement with a unique combination of amino acids specific to the nervous system, effectively supporting mental abilities, indicated in conditions of stress, overwork, and mild forms of anxiety and depression. Each capsule contains $68 \mathrm{mg}$ of amino acids, where Tyr is found in a concentration of $4.012 \mathrm{mg}$ per capsule.

The second product, Tiroidin, comes from the manufacturer PARAPHARM Romania and, besides the $90 \mathrm{mg}$ Tyr, contains spirulina, vitamin E, selenium, and iodine. The last product, L-Tyrosine SOLARAY U.S., with a content of $500 \mathrm{mg}$ L-Tyr obtained by bacterial fermentation, is intended for people who suffer from fatigue, depression, or excessive sleepiness, or in situations where their body cannot synthesize the necessary phenylalanine. On the other hand, it increases focus and learning capacity, attention, and motivation, and improves the body's ability to cope with stress factors. 


\section{Results}

Since the sensor-doping process by the CA method was mentioned in the paper by the same authors in which the PPy/FeCN/SPCE sensor was fabricated [20], this section will highlight the importance of the Lacc enzyme in the detection of Tyr in pharmaceuticals, mentioning the performance of the new biosensor compared to the sensor.

\subsection{Cyclic Voltammetry Characterization}

The CV method was used to characterize the SPCE electrode modified with monomer/ doping-agent solution and laccase. Thus, the three electrodes, i.e., the working electrode, the counter electrode, and the reference electrode, were immersed in two solutions: an inactive solution of $0.1 \mathrm{M} \mathrm{KCl}$ and a double solution of $0.1 \mathrm{M} \mathrm{KCl}-10^{-3} \mathrm{M} \mathrm{L}-\mathrm{Tyr}$, recording voltammograms in the potential range of -1.0 to $0.5 \mathrm{~V}$.

\subsubsection{Stable Electrochemical Responses of Biosensors in $0.1 \mathrm{M} \mathrm{KCl}$ Solutions and in a} Double Solution of $0.1 \mathrm{M} \mathrm{KCl}-10^{-3} \mathrm{M}$ L-Tyr

After doping PPy with FeCN by the CA method and after the immobilization of the Lacc enzyme on the electrode surface, the biosensor was placed in a $0.1 \mathrm{M} \mathrm{KCl}$ solution. Initially, the behavior of the biosensor in $\mathrm{KCl}$ solution was analyzed, as it is an inactive solution that allows the subsequent detection of specific Tyr peaks. For the stability of the biosensor, six cycles were recorded at a scan rate of $0.1 \mathrm{~V} \cdot \mathrm{s}^{-1}$, during which time PPy and Lacc stabilization in the electrolyte solution took place. This is illustrated in Figure 3a.
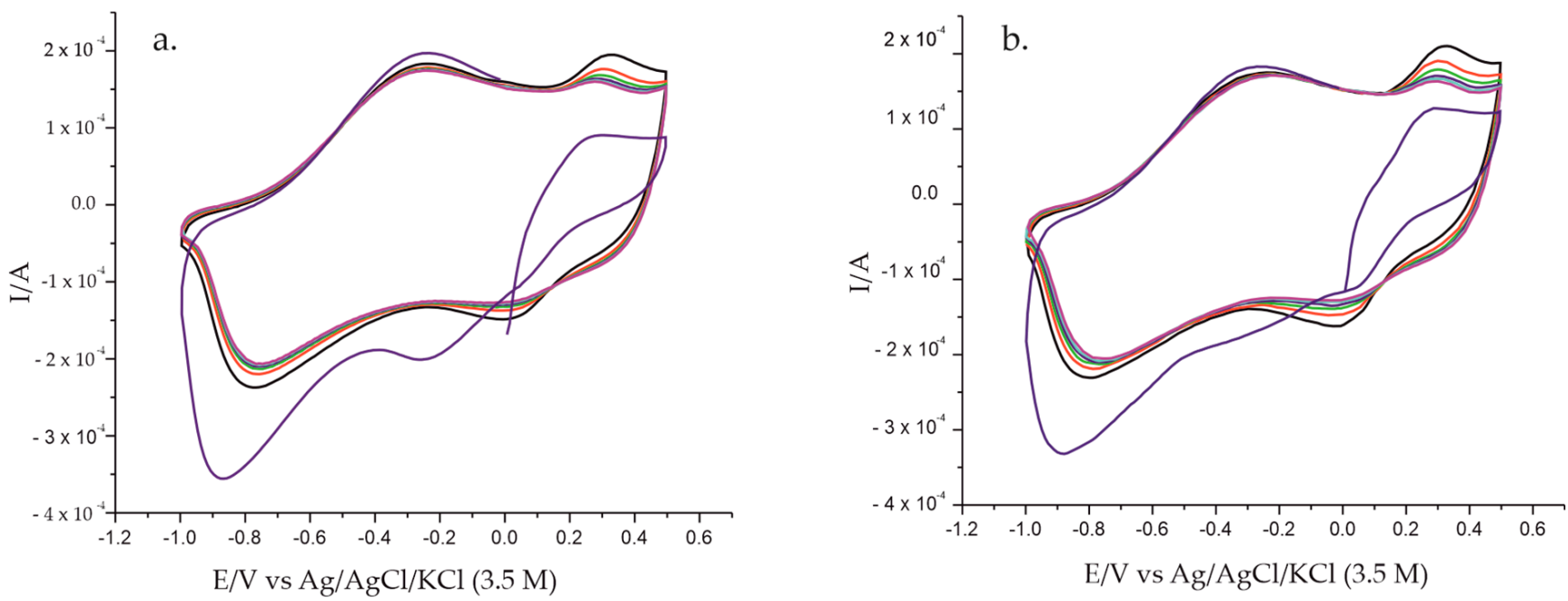

Figure 3. Stabilization of the Ppy/FeCN/Lacc/SPCE biosensor response immersed in (a) $0.1 \mathrm{M} \mathrm{KCl}$ solution; (b) $0.1 \mathrm{M} \mathrm{KCl}-10^{-3} \mathrm{M} \mathrm{L}-\mathrm{Tyr}$ double solution.

Furthermore, for another biosensor prepared under the same conditions, six cycles were recorded for stabilization purposes at the same scan rate but in double solution, i.e., in $0.1 \mathrm{M} \mathrm{KCl}-10^{-3} \mathrm{M} \mathrm{L-Tyr}$ (Figure $3 \mathrm{~b}$ ). The stable responses in electrolyte solutions were recorded starting with the sixth cycle in both cases, the first cycles having a different representation compared to the subsequent ones. Increased anodic and cathodic peak intensities were observed for the sensor immersed in double solution. Thus, in Table 1 the peak intensities for both redox systems at the same potential for the sixth cycle after stabilization of the PPy/FeCN/Lacc/SPCE biosensor immersed in the two solutions are reported.

A comparative study was also carried out on the stable responses of the non-enzymatic sensor with those of the enzymatic sensor, first in inactive $0.1 \mathrm{M} \mathrm{KCl}$ solution at the same scan rate, i.e., $0.1 \mathrm{~V} \cdot \mathrm{s}^{-1}$. The recorded voltammetric response is illustrated in Figure 4 and accompanied by Table 2, which details the intensities and potential of the peaks obtained with both devices. 
Table 1. Electrochemical parameters of PPy/FeCN/Lacc/SPCE biosensor immersed in two electrolyte solutions: $0.1 \mathrm{M} \mathrm{KCl}$ and $0.1 \mathrm{M} \mathrm{KCl}-10^{-3} \mathrm{M} \mathrm{L-Tyr.}$

\begin{tabular}{|c|c|c|c|c|c|c|c|c|c|}
\hline \multirow{2}{*}{\multicolumn{2}{|c|}{ Biosensor Electrolyte Solution }} & \multicolumn{4}{|c|}{ Redox System I } & \multicolumn{4}{|c|}{ Redox System II } \\
\hline & & $\begin{array}{l}\mathrm{E}_{\mathrm{pa}}{ }^{1} \\
\text { (V) }\end{array}$ & $\begin{array}{l}\mathrm{I}_{\mathrm{pa}}{ }^{2} \\
(\mathrm{~A})\end{array}$ & $\begin{array}{l}\mathrm{E}_{\mathrm{pc}}{ }^{3} \\
(\mathrm{~V})\end{array}$ & $\begin{array}{l}\mathrm{I}_{\mathrm{pc}} 4 \\
(\mathrm{~A})\end{array}$ & $\begin{array}{l}E_{p a} \\
\text { (V) }\end{array}$ & $\begin{array}{l}I_{\mathrm{pa}} \\
(\mathrm{A})\end{array}$ & $\begin{array}{l}\mathrm{E}_{\mathrm{pc}} \\
(\mathrm{V})\end{array}$ & $\begin{array}{l}I_{p c} \\
(A)\end{array}$ \\
\hline \multirow[b]{2}{*}{$\mathrm{PPy} / \mathrm{FeCN} / \mathrm{Lacc} / \mathrm{SPCE}$} & $0.1 \mathrm{M} \mathrm{KCl}$ & \multirow[b]{2}{*}{-0.23} & $1.6 \times 10^{-4}$ & \multirow[b]{2}{*}{-0.73} & $-2.05 \times 10^{-4}$ & \multirow[b]{2}{*}{0.29} & $1.5 \times 10^{-4}$ & \multirow[b]{2}{*}{0.04} & $-1.23 \times 10^{-4}$ \\
\hline & $\begin{array}{c}0.1 \mathrm{M} \mathrm{KCl}- \\
10^{-3} \mathrm{M} \mathrm{L}-\mathrm{Tyr}\end{array}$ & & $1.7 \times 10^{-4}$ & & $-2.06 \times 10^{-4}$ & & $1.6 \times 10^{-4}$ & & $-1.24 \times 10^{-4}$ \\
\hline
\end{tabular}

${ }^{1} \mathrm{E}_{\mathrm{pa}}$, anodic peak potential; ${ }^{2} \mathrm{I}_{\mathrm{pa}}$, anodic peak current; ${ }^{3} \mathrm{E}_{\mathrm{pc}}$, cathodic peak potential; ${ }^{4} \mathrm{I}_{\mathrm{pc}}$, cathodic peak current.

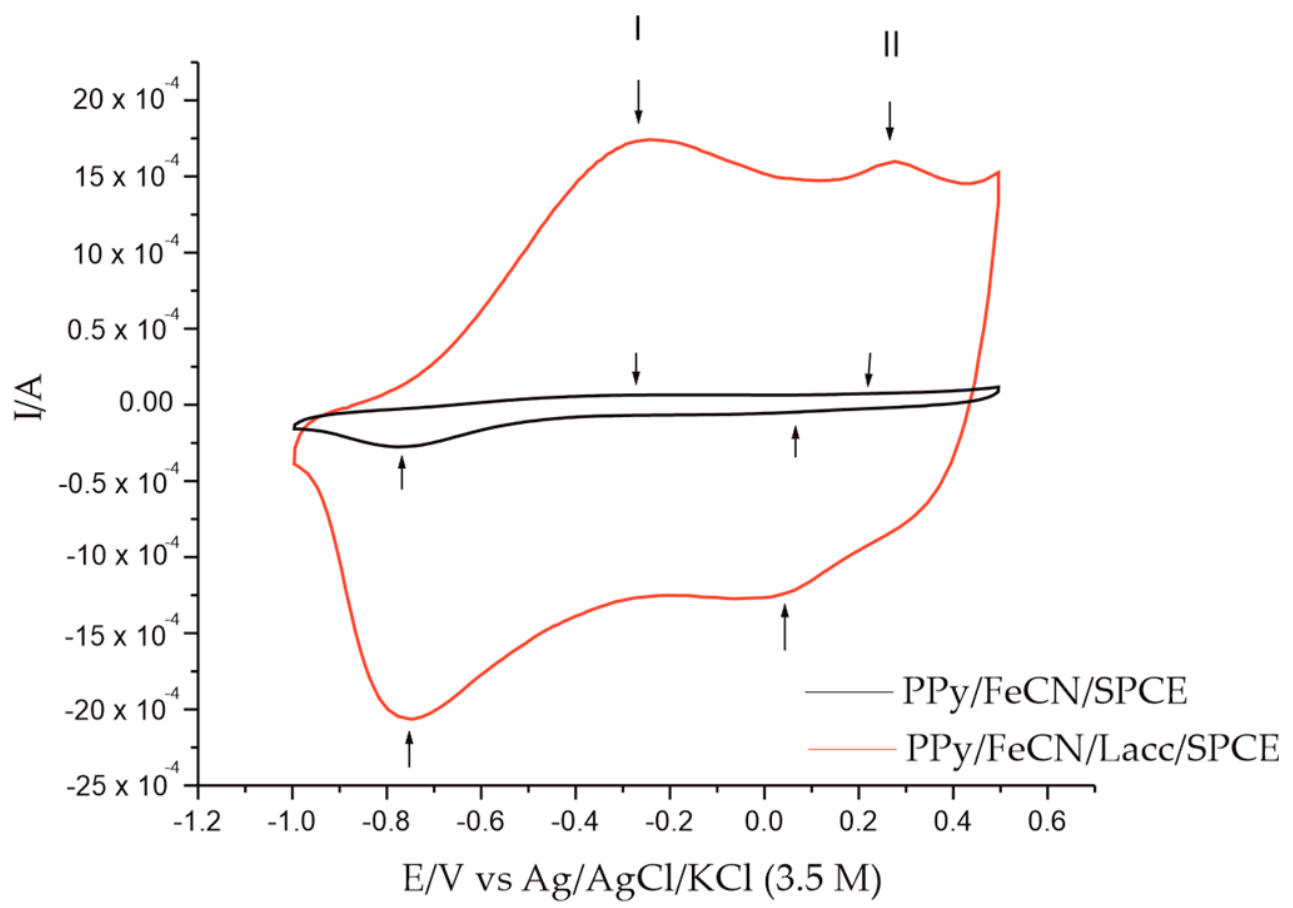

Figure 4. Stable responses of the PPy/FeCN/SPCE sensor and the PPy/FeCN/Lacc/SPCE biosensor immersed in $0.1 \mathrm{M} \mathrm{KCl}$.

Table 2. Electrochemical parameters obtained from the voltamograms of the PPy/FeCN/SPCE sensor and the PPy/FeCN/Lacc/SPCE biosensor immersed in $0.1 \mathrm{M} \mathrm{KCl}$ solution.

\begin{tabular}{|c|c|c|c|c|c|c|c|}
\hline \multirow[b]{2}{*}{ Electrode } & & \multicolumn{6}{|c|}{ Electrochemical Parameters } \\
\hline & & $\begin{array}{c}E_{p a}{ }^{1} \\
(V)\end{array}$ & $\begin{array}{c}E_{p c}^{2} \\
(V)\end{array}$ & $\begin{array}{c}\Delta \mathrm{E}^{3} \\
(\mathrm{~V})\end{array}$ & $\begin{array}{c}\mathrm{I}_{\mathrm{pa}}{ }^{4} \\
\text { (A) }\end{array}$ & $\begin{array}{c}\mathrm{I}_{\mathrm{pc}}{ }^{5} \\
(\mathrm{~A})\end{array}$ & $\mathrm{I}_{\mathrm{pc}} / \mathrm{I}_{\mathrm{pa}}$ \\
\hline \multirow{2}{*}{ PPy/FeCN/SPCE sensor [20] } & Redox system I & -0.32 & -0.74 & 0.42 & $6 \times 10^{-6}$ & $-2 \times 10^{-5}$ & 4.31 \\
\hline & Redox system II & 0.20 & 0.03 & 0.17 & $7.2 \times 10^{-6}$ & $-4.9 \times 10^{-6}$ & 0.69 \\
\hline \multirow{2}{*}{$\mathrm{PPy} / \mathrm{FeCN} / \mathrm{Lacc} / \mathrm{SPCE}$ biosensor } & Redox system I & -0.26 & -0.74 & 0.48 & $1.7 \times 10^{-4}$ & $-2 \times 10^{-4}$ & 1.18 \\
\hline & Redox system II & 0.26 & 0.03 & 0.23 & $1.5 \times 10^{-4}$ & $-1.2 \times 10^{-4}$ & 0.78 \\
\hline
\end{tabular}

${ }^{1} \mathrm{E}_{\mathrm{pa}}$, anodic peak potential; ${ }^{2} \mathrm{I}_{\mathrm{pa}}$, anodic peak current; ${ }^{3} \Delta \mathrm{E}=\mathrm{E}_{\mathrm{pa}}-\mathrm{E}_{\mathrm{pc}} ;{ }^{4} \mathrm{E}_{\mathrm{pc}}$, cathodic peak potential; ${ }^{5} \mathrm{I}_{\mathrm{pc}}$, cathodic peak current.

As shown in Figure 4 and Table 2, the benefits of the immobilized enzyme on the Ppy / FeCN/SPCE sensor can easily be observed. In the case of the biosensor, the $\mathrm{I}_{\mathrm{pc}} / \mathrm{I}_{\mathrm{pa}}$ ratio showed the value closest to the ideal value, i.e., 1, especially in the case of redox system I, the system corresponding to the redox processes of PPy. The peak intensities of the biosensor had increased values, especially in the cathodic scan, compared to those of 
the sensor, due on the one hand to the conductive polymer and the anion, and on the other to the Lacc enzyme, which conferred an increased sensitivity to the biosensor. A reduction in the background current for the biosensor can also be observed, with the differences between the two devices being obvious.

The next test of the biosensor was to immerse it in the double solution of $0.1 \mathrm{M} \mathrm{KCl}$ and $0.1 \mathrm{M} \mathrm{KCl}-10^{-3} \mathrm{M} \mathrm{L}-\mathrm{Tyr}$ under the same conditions and parameters used for the inactive solution. The stable response is illustrated in Figure 5. The values of the electrochemical parameters obtained in this step are listed in Table 3.

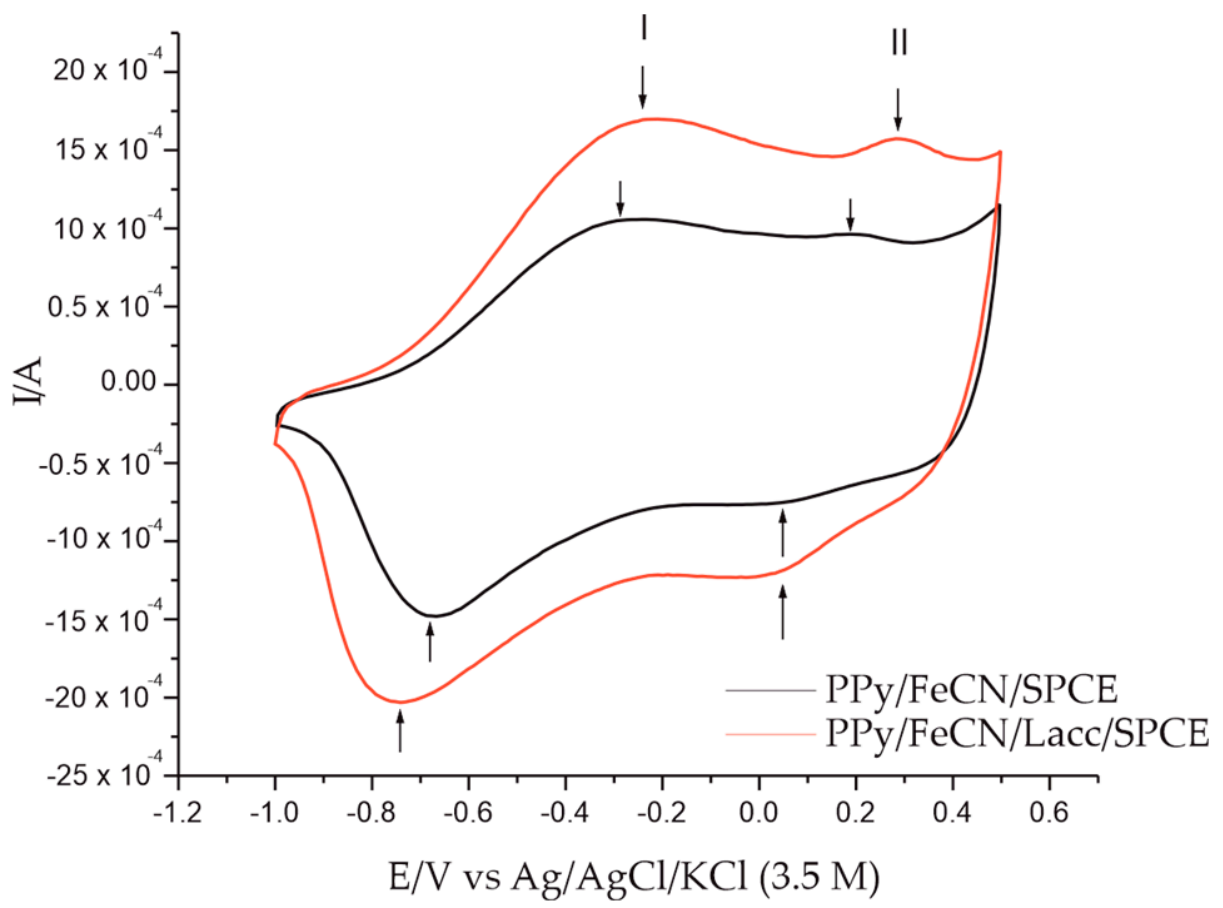

Figure 5. Stable response of the PPy/FeCN/SPCE sensor and the PPy/FeCN/Lacc/SPCE biosensor immersed in $0.1 \mathrm{M} \mathrm{KCl}-10^{-3} \mathrm{M} \mathrm{L-Tyr}$ double solution. I-Redox system I; II-Redox system II.

Table 3. Electrochemical parameters obtained from the voltamograms of the PPy/FeCN/SPCE sensor and the PPy/FeCN/Lacc/SPCE biosensor immersed in $0.1 \mathrm{M} \mathrm{KC}-10^{-3} \mathrm{M} \mathrm{L-Tyr} \mathrm{solution.}$

\begin{tabular}{|c|c|c|c|c|c|c|c|}
\hline \multirow[b]{2}{*}{ Electrode } & & \multicolumn{6}{|c|}{ Electrochemical Parameters } \\
\hline & & $\begin{array}{c}\mathrm{E}_{\mathrm{pa}}{ }^{1} \\
(\mathrm{~V})\end{array}$ & $\begin{array}{c}E_{p c}{ }^{2} \\
(V)\end{array}$ & $\begin{array}{c}\Delta E^{3} \\
(V)\end{array}$ & $\begin{array}{c}\mathrm{I}_{\mathrm{pa}}{ }^{4} \\
(\mathrm{~A})\end{array}$ & $\begin{array}{c}\mathrm{I}_{\mathrm{pc}}{ }^{5} \\
(\mathrm{~A})\end{array}$ & $\mathrm{I}_{\mathrm{pc}} / \mathrm{I}_{\mathrm{pa}}$ \\
\hline \multirow{2}{*}{ PPy/FeCN/SPCE sensor [20] } & Redox system I & -0.28 & -0.66 & -0.38 & $1.2 \times 10^{-4}$ & $-1.3 \times 10^{-4}$ & 1.09 \\
\hline & Redox system II & 0.19 & 0.08 & 0.11 & $9.4 \times 10^{-5}$ & $-8.5 \times 10^{-5}$ & 0.90 \\
\hline \multirow{2}{*}{$\mathrm{PPy} / \mathrm{FeCN} / \mathrm{Lacc} / \mathrm{SPCE}$ biosensor } & Redox system I & -0.20 & -0.74 & 0.54 & $1.7 \times 10^{-4}$ & $-2 \times 10^{-4}$ & 1.19 \\
\hline & Redox system II & 0.26 & 0.04 & 0.22 & $1.5 \times 10^{-4}$ & $-1.1 \times 10^{-4}$ & 0.75 \\
\hline
\end{tabular}

${ }^{1} \mathrm{E}_{\mathrm{pa}}$, anodic peak potential; ${ }^{2} \mathrm{I}_{\mathrm{pa}}$, anodic peak current; ${ }^{3} \Delta \mathrm{E}=\mathrm{E}_{\mathrm{pa}}-\mathrm{E}_{\mathrm{pc}} ;{ }^{4} \mathrm{E}_{\mathrm{pc}}$, cathodic peak potential; ${ }^{5} \mathrm{I}_{\mathrm{pc}}$, cathodic peak current

A first noteworthy observation is the difference obtained by the non-zero electrode in the two solutions, $0.1 \mathrm{M} \mathrm{KCl}$ and the double solution $0.1 \mathrm{M} \mathrm{KCl}-10^{-3} \mathrm{M} \mathrm{L}-\mathrm{Tyr}$. This is explained by the presence of more intense peaks in the double solution due to the presence of AA L-Tyr. Another significant difference is that on the one hand, between the sensor and the biosensor, the intensities of the peaks were increased both at the level of redox system I, corresponding to PPy, and at the level of redox system II, corresponding to the 
potassium ferrocyanide included in the polymer matrix, and on the other hand the Lacc enzyme provided better selectivity and accuracy to the biosensor.

\subsubsection{Effect of the Scan Rate on PPy/FeCN/Lacc/SPCE Immersed in Double Solution $0.1 \mathrm{M} \mathrm{KCl}$ and $0.1 \mathrm{M} \mathrm{KCl}-10^{-3} \mathrm{M} \mathrm{L-Tyr}$}

At this stage, the influence of the scan rate was studied for the PPy/FeCN/Lacc/SPCE biosensor immersed in $0.1 \mathrm{M} \mathrm{KCl}-10^{-3} \mathrm{M} \mathrm{L-Tyr} \mathrm{electrolyte} \mathrm{solution,} \mathrm{with} \mathrm{cyclic} \mathrm{voltam-}$ mograms recorded at different scan rates, i.e., between 0.1 and $1.0 \mathrm{~V} \cdot \mathrm{s}^{-1}$, using the same potential range mentioned in the previous stage. The kinetic parameters can be investigated with the Tafel plot [37], illustrated in Figure 6, when the mechanism is diffusion. The oxidation and reduction peaks were in close dependence with the scan rate, and increasing the latter led to higher peak intensities (Figure 6a). Figure $6 \mathrm{~b}$ shows the linear dependence between the peak or peak current intensity and the square root of the scan rate, with the correlation coefficient being 0.9988 for the anodic peak and 0.9985 for the cathodic peak.
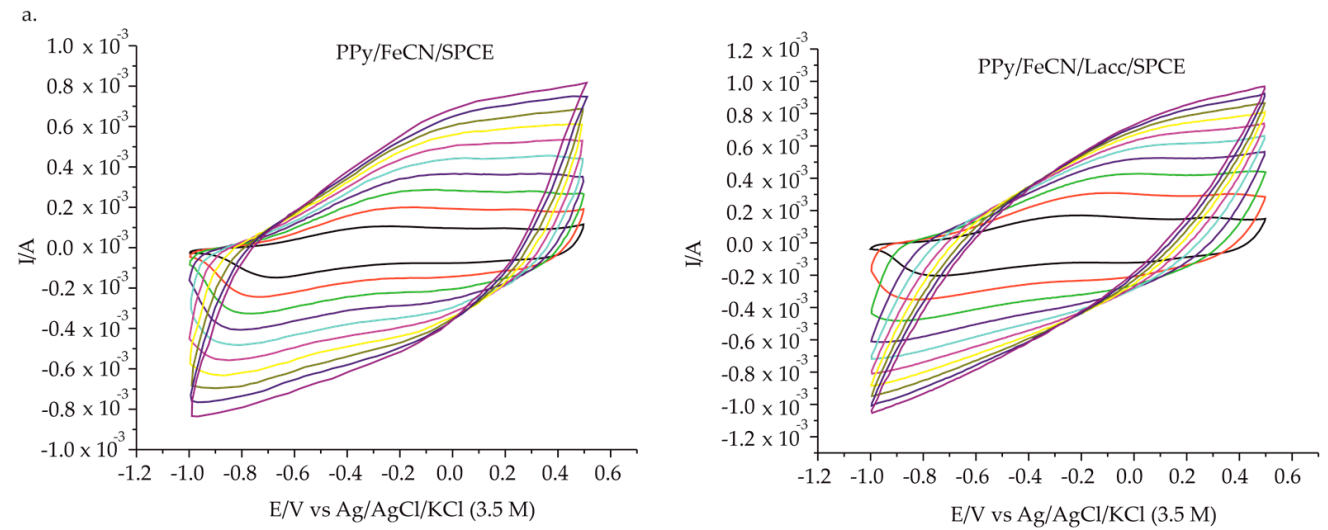

b
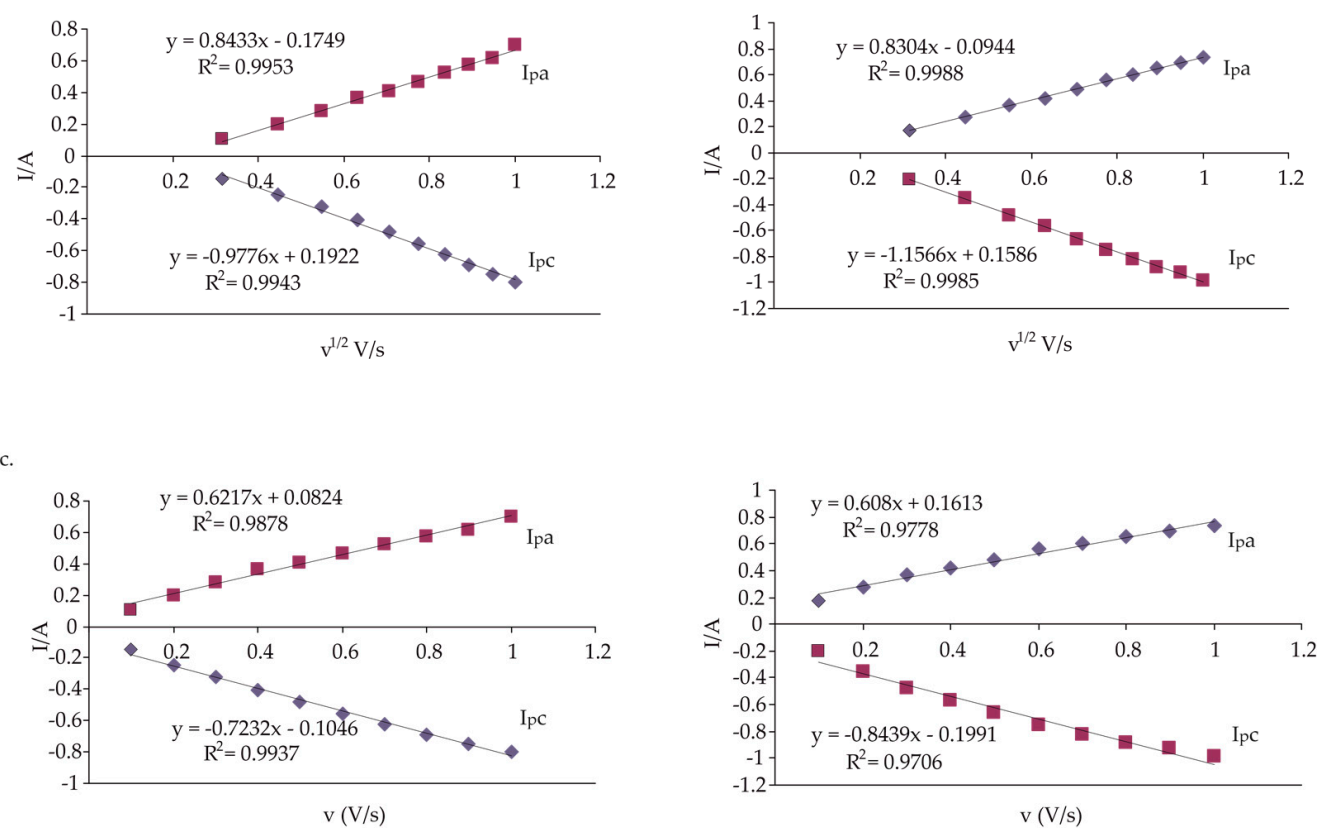

Figure 6. (a) $\mathrm{CVs}$ for $\mathrm{PPy} / \mathrm{FeCN} / \mathrm{SPCE}$ at different scan rates of $0.1-1.0 \mathrm{~V} \cdot \mathrm{s}^{-1}$ in the double solution of $0.1 \mathrm{M} \mathrm{KCl}$ and $0.1 \mathrm{M} \mathrm{KCl}-10^{-3} \mathrm{M} \mathrm{L-Tyr}$; (b) dependence between the square root of the scan rates and the intensity of the anodic and cathodic peaks; (c) dependence between scan rate and intensity of the anodic and cathodic peaks.

The curve obtained for the cathodic peak of redox system I for both the biosensor and non-enzymatic sensor, extracted from the intensity plot as a function of the square root of 
the scan rate, was thus considered. Subsequently, the active area for both electrodes was calculated, and the values obtained are given in Table 4.

Under these circumstances, according to the data obtained, the redox process was influenced by the diffusion process. The diffusion coefficient for L-Tyr is $3 \times 10^{-5} \mathrm{~cm}^{2} \cdot \mathrm{s}^{-1}$, a value that allowed for the calculation of the active area of the PPy/FeCN/Lacc/SPCE biosensor, as shown in Table 4. The Randles-Sevcik equation describes the influence of the scan rate against peak intensity. According to this equation, the cathodic peak intensity $\left(\mathrm{I}_{\mathrm{pc}}, \mathrm{A}\right)$ is the product of 268.600 , the number of electrons transferred in redox processes $\left(\mathrm{n}^{3 / 2}\right)$, the area of the electrode active surface $\left(\mathrm{A} / \mathrm{cm}^{2}\right)$, the diffusion coefficient $\left(\mathrm{D}, \mathrm{cm}^{2} \cdot \mathrm{s}^{-1}\right)$, the concentration $\left(\mathrm{C}, \mathrm{mol} \cdot \mathrm{cm}^{-3}\right)$, and the scan rate $\left(\mathrm{v}^{1 / 2}, \mathrm{~V} \cdot \mathrm{s}^{-1}\right)[38]$.

Table 4. The area of the active surface of the sensor and the biosensor corresponding to the cathodic peak of redox system I.

\begin{tabular}{ccccccc}
\hline Electrode & Solution & Slope & $\mathbf{R}^{2}$ & Active Area $\left(\mathbf{c m}^{2}\right)$ & Geometric Area & Roughness Factor \\
\hline $\begin{array}{c}\text { PPy/FeCN/SPCE } \\
\text { sensor [20] }\end{array}$ & $\begin{array}{c}0.1 \mathrm{M} \mathrm{KCl} \text { and } \\
0.1 \mathrm{M} \mathrm{KCl}- \\
10^{-3} \mathrm{M} \mathrm{L-Tyr}\end{array}$ & -0.0009776 & 0.9943 & 1.3488 & & 10.74 \\
\cline { 1 - 5 } $\begin{array}{c}\text { PPy/FeCN/Lacc/ } \\
\text { SPCE biosensor }\end{array}$ & -0.0011566 & 0.9985 & 1.5957 & 0.1256 & 12.70 \\
\hline
\end{tabular}

Therefore, according to the graphs in Figures 4-6, it can be seen that, in addition to the electropolymerization of pyrrole and the general doping process [39], the action of the metalloenzyme Lacc, which is an oxidoreductase and in which the electron transfer is via copper ions, was also involved. Thus, Lacc catalyzed the oxidation reaction of Tyr to 3,4-dioxyphenylalanine, where it oxidized to the respective quinone, which appeared as an intermediate in the synthesis of melanin pigments [40]. The mechanism of the enzymic action is illustrated in the following reactions:

$$
\begin{gathered}
\text { Tyr }+\mathrm{Lac}\left(\text { oxy) } \rightarrow \text { 3,4- dioxyphenylalanine }+\mathrm{Lac}\left(\text { deoxy) }+2 \mathrm{H}^{+}+2 \mathrm{e}^{-}\right.\right. \\
\mathrm{Lac}\left(\text { deoxy) }+\mathrm{O}_{2}+4 \mathrm{H}^{+} \rightarrow \mathrm{Lac} \text { (oxy) }+2 \mathrm{H}_{2} \mathrm{O}\right.
\end{gathered}
$$

The redox process at the biosensor surface showed a quasi-reversible nature, with the anodic peak potential shifting to some extent towards the positive potential as the scanning rate increased, whereas the cathodic peak potential shifted moderately towards the negative potential.

\subsubsection{Calibration Curve and Detection Limit of the PPy/FeCN/Lacc/SPCE Biosensor}

Cyclic voltammograms for the detection of L-Tyr in solutions of different concentrations of $0.1 \mathrm{M} \mathrm{KCl}-10^{-3} \mathrm{M} \mathrm{L}-\mathrm{Tyr}$, in the potential range of -1.0 to $0.5 \mathrm{~V}$ and in the concentration range of $0.09-27 \times 10^{-6} \mathrm{M}$, were obtained for the two devices, as shown in Figure 7.

Figure 7a displays the relationship between the cathodic current of the sensor and the biosensor, and the concentration of L-Tyr by the CV technique. The linearity ranges identified in Figure $7 \mathrm{~b}$ were between 0.09 and $7 \times 10^{-6} \mathrm{M}$ for the sensor and from 0.2 to $7 \times 10^{-6} \mathrm{M}$ for the biosensor. Figure $7 \mathrm{c}$ illustrates the calibration curves for both the sensor and the biosensor, with correlation coefficients $\mathrm{R}^{2}$ equal to 0.95 for the sensor and 0.99 for the biosensor, and a detection limit of $3.76 \times 10^{-7}$ for the sensor and $2.29 \times 10^{-8}$ for the biosensor (Table 5). 

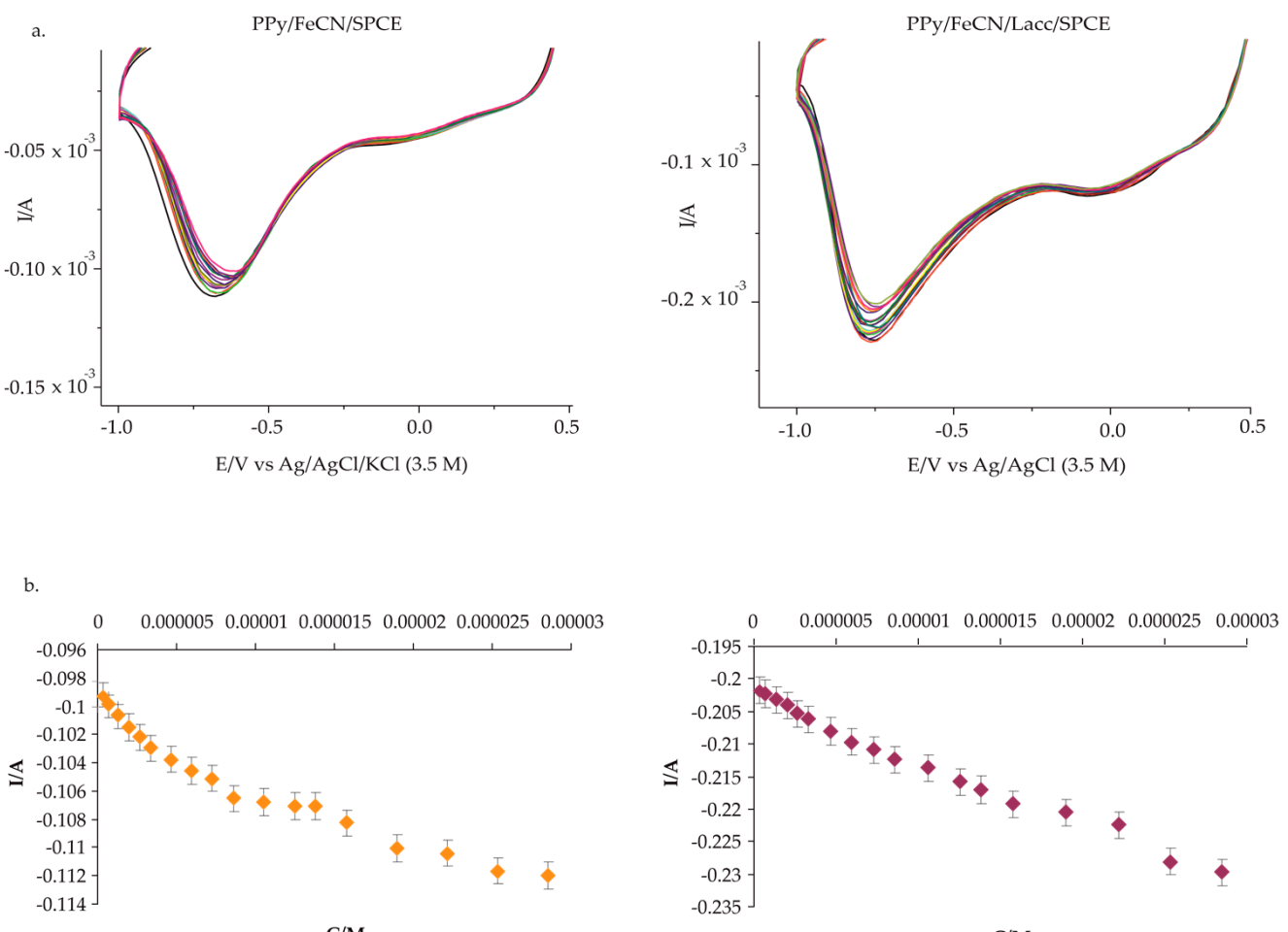

C/M

C/M
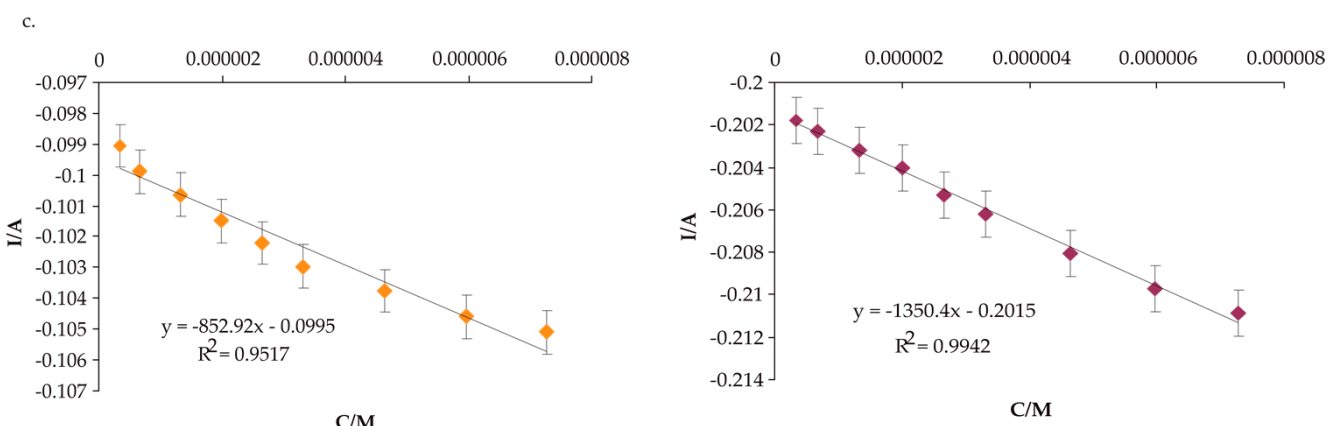

C/M

Figure 7. (a) The relationship between the cathodic peak of the sensor and the biosensor, and the concentration of the $0.1 \mathrm{M} \mathrm{KCl}-10^{-3} \mathrm{M}$ L-Tyr solution; (b) the cathodic peak current I variation with Tyr concentration; (c) the sensor and biosensor calibration curves in the concentration range of $0.09-7 \times 10^{-6} \mathrm{M}$ and $0.2-7 \times 10^{-6} \mathrm{M}$, respectively.

Table 5. Data obtained for the calibration curves of the Ppy/FeCN/SPCE sensor and the Ppy/FeCN/Lacc/SPCE biosensor at L-Tyr detection.

\begin{tabular}{ccc}
\hline Electrode & LOD $^{\mathbf{1}} \mathbf{( M )}$ & LOQ $^{\mathbf{2}} \mathbf{( M )}$ \\
\hline $\mathrm{PPy} / \mathrm{FeCN} / \mathrm{SPCE}$ sensor [20] & $3.76 \times 10^{-7}$ & $1.25 \times 10^{-6}$ \\
\hline $\mathrm{PPy} / \mathrm{FeCN} /$ Lacc/SPCE biosensor & $2.29 \times 10^{-8}$ & $7.63 \times 10^{-8}$ \\
\hline
\end{tabular}

${ }^{1}$ Limit of detection; ${ }^{2}$ limit of quantification.

3.1.4. Quantitative Determination of L-Tyr at PPy/FeCN/Lacc/SPCE in Pharmaceutical Samples by the CV Method and Standard FT-IR Method for Biosensor Validation

The selection of samples for biosensor validation was carried out for the purpose of quality control of the pharmaceutical products, as there is no research to date with an enzyme sensor for such a study. Because there are many products with different concentrations of tyrosine from different manufacturers on the pharmaceutical market, only three pharmaceutical products were selected and investigated similarly by CV for this 
study: Cebrium, with $4.012 \mathrm{mg}$ per capsule of L-Tyr; Tiroidin, with $90 \mathrm{mg}$ per capsule of L-Tyr; and L-Tyrosine, with $500 \mathrm{mg}$ per capsule of L-Tyr.

The analytical performance of the PPy/FeCN/Lacc/SPCE biosensor demonstrated selective detection of Tyr, including from multicomponent solutions, such as the solution obtained from the Cebrium product. The Lacc enzyme gave the biosensor increased efficiency and accuracy over this AA.

Quantitative determination of L-Tyr was performed by the standard addition method for each pharmaceutical product. Figure 8 shows the CV responses of the PPy/FeCN/Lacc/ SPCE biosensor prepared for each sample. The prepared solutions of each pharmaceutical product had different concentrations of L-Tyr: $3 \times 10^{-6}, 4 \times 10^{-6}$, and $5 \times 10^{-6} \mathrm{M}$.

Biosensor validation was performed by the FT-IR method. The electroanalytical results for the quantification of L-Tyr obtained by the CV method based on the biosensor developed in this study were compared both with those obtained by the FT-IR method and with those provided by the producers of the pharmaceutical products under analysis. The results obtained are included in Table 6.

Measurements with the biosensors prepared under the same conditions led to the following coefficient of variation results (Table 6).

The quantification of L-Tyr by the FT-IR method was performed by analyzing three standards obtained by mixing pure L-Tyr with $\mathrm{KBr}$, with concentrations similar to those of the studied pharmaceuticals: $5 \mathrm{mg} / \mathrm{g}, 100 \mathrm{mg} / \mathrm{g}$, and $500 \mathrm{mg} / \mathrm{g}$. For the quantitative determination of L-Tyr, the absorbance of the peak at $1650 \mathrm{~cm}^{-1}$, characteristic of the $\mathrm{N}-\mathrm{H}$ group vibration (bending), was taken into account.

As can be observed in Table 6, the L-Tyr concentration values of the results obtained by the CV method and the FT-IR method, and those provided by the pharmaceutical manufacturers, are similar, with small differences, which demonstrates the accuracy of the L-Tyr quantification method developed in this biosensor-based research. Therefore, the biosensor could be applied in laboratory practice in the quality control of pharmaceutical products containing L-Tyr, but also for analyses of L-Tyr in biological fluids.

Finally, measurements were made in real samples with the biosensor using the standard addition method. In order to measure real samples, three capsules of Tiroidin were crushed and homogenized, and after this, some of the powder was dissolved in $0.1 \mathrm{M} \mathrm{KCl}$ solution to prepare a stock solution. Insoluble excipients were separated by filtration. Using the stock solution, a $1.5 \mu \mathrm{M}$ L-Tyr solution was prepared by dilution and the biosensor response in this solution was recorded. Then, $1.5 \mu \mathrm{M} \mathrm{L}$-Tyr was added to the real sample solution and the biosensor response was recorded again. As shown in Table 7, the analytical recoveries were good, and the relative standard deviation for seven successive determinations was less than $5 \%$. This study shows that the biosensor showed good analytical performance in real samples.

These results highlight the applicability of the biosensor in the pharma-medical field. The recovery percentage clearly demonstrates the efficiency of the voltammetric method in the analysis and quantification of L-Tyr in pharmaceuticals. 

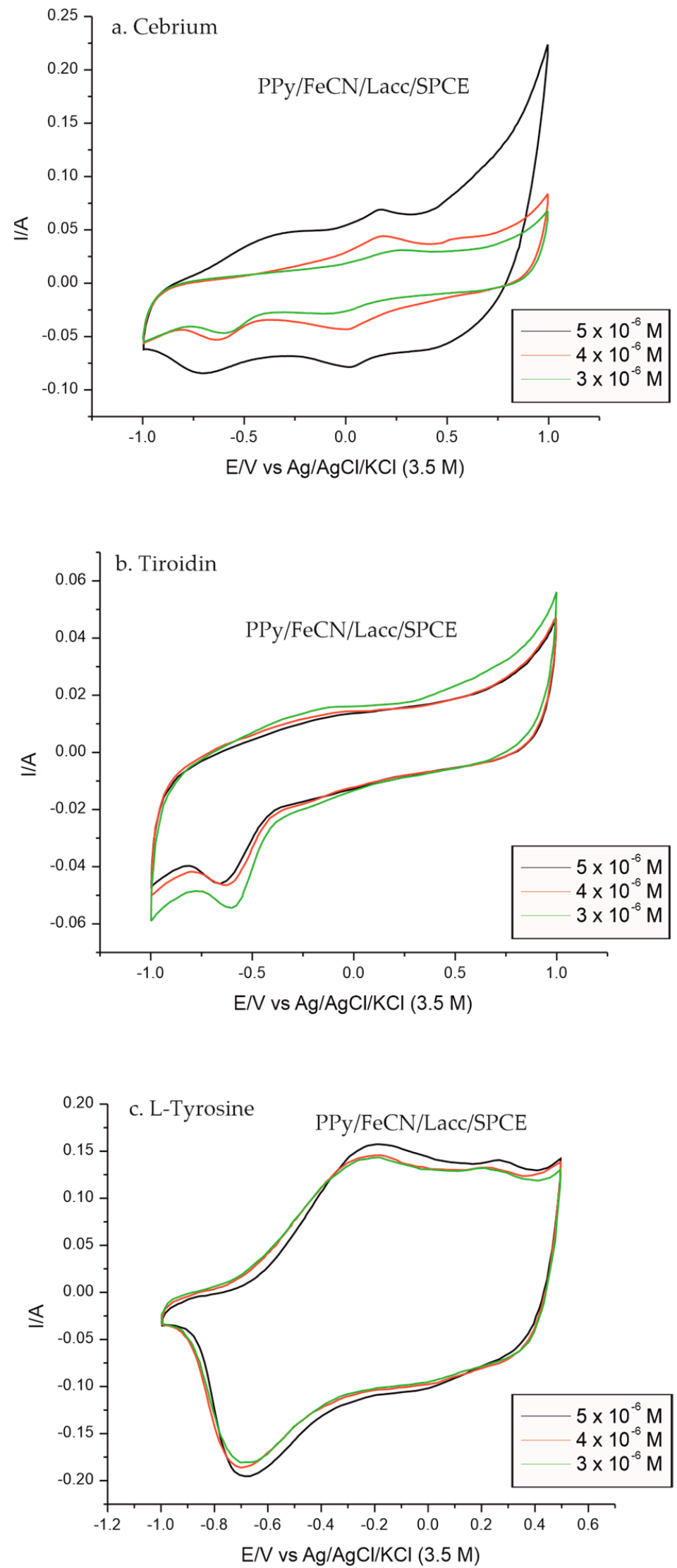

Figure 8. Cyclic voltamograms of the PPy/FeCN/Lacc/SPCE biosensor, recorded at a scan rate of $0.1 \mathrm{~V} \cdot \mathrm{s}^{-1}$ at three concentrations of $3 \times 10^{-6}, 4 \times 10^{-6}$, and $5 \times 10^{-6} \mathrm{M}$ and immersed in (a) Cebrium solution, (b) Tiroidin solution, and (c) L-Tyrosine solution. 
Table 6. Results obtained by the prepared biosensor regarding the concentration of L-Tyr from the selected pharmaceutical products compared to those mentioned by the manufacturer and determined by the FT-IR method.

\begin{tabular}{ccccc}
\hline $\begin{array}{c}\text { Pharmaceutical } \\
\text { Product }\end{array}$ & Manufacturer & $\begin{array}{c}\text { L-Tyr in the Pharmaceutical } \\
\text { Product/mg per Capsule }\end{array}$ & $\begin{array}{c}\text { L-Tyr Determined by } \\
\text { CV/mg per Capsule }\end{array}$ & $\begin{array}{c}\text { L-Tyr Determined by } \\
\text { FT-IR/mg per Capsule }\end{array}$ \\
\hline Cebrium & $\begin{array}{c}\text { EVER Neuro } \\
\text { Pharma }\end{array}$ & 4.012 & 4.124 & 4.131 \\
\hline Tiroidin & Parapharm & 90 & 92.34 & 92.98 \\
\hline L-Tyrosine & Solaray & 500 & 477.5 & 478.3 \\
\hline
\end{tabular}

Table 7. Tyr analysis data from the pharmaceutical product Tiroidin.

\begin{tabular}{cccc}
\hline Sample & Added $(\mu \mathbf{M})$ & Found $(\mu \mathbf{M})$ & Recovery $(\%)$ \\
\hline 1 & 1.5 & 1.46 & 97.34 \\
\hline 2 & 3.0 & 3.07 & 102.34 \\
\hline 3 & 4.5 & 4.48 & 99.55 \\
\hline 4 & 6.0 & 6.85 & 97.50 \\
\hline
\end{tabular}

3.2. Repeatability, Reproducibility, Stability, and Interference Study of the Biosensor

Series of five successive CV measurements with $10^{-5} \mathrm{M}$ Tyr, each recorded on a new modified biosensor, produced relative standard deviations of $2.8 \%$. The results indicate that the biosensor provides good reproducibility in the electrochemical detection of L-Tyr.

The stability of the biosensor in the detection of L-Tyr was also determined when the biosensor was stored in the refrigerator for 15 days. The response was recorded in $10^{-5} \mathrm{M}$ solution, and L-Tyr was found to be stable, maintaining $90 \%$ of its original intensity.

The reproducibility of the fabrication process was also studied. Five biosensors were prepared in identical conditions and the responses in $10^{-5} \mathrm{M}$ L-Tyr were registered. As can be observed in Figure 9, the differences between the biosensor responses were small, with the relative standard deviation (RSD) being $2.7 \%$.

\section{Biosensor}

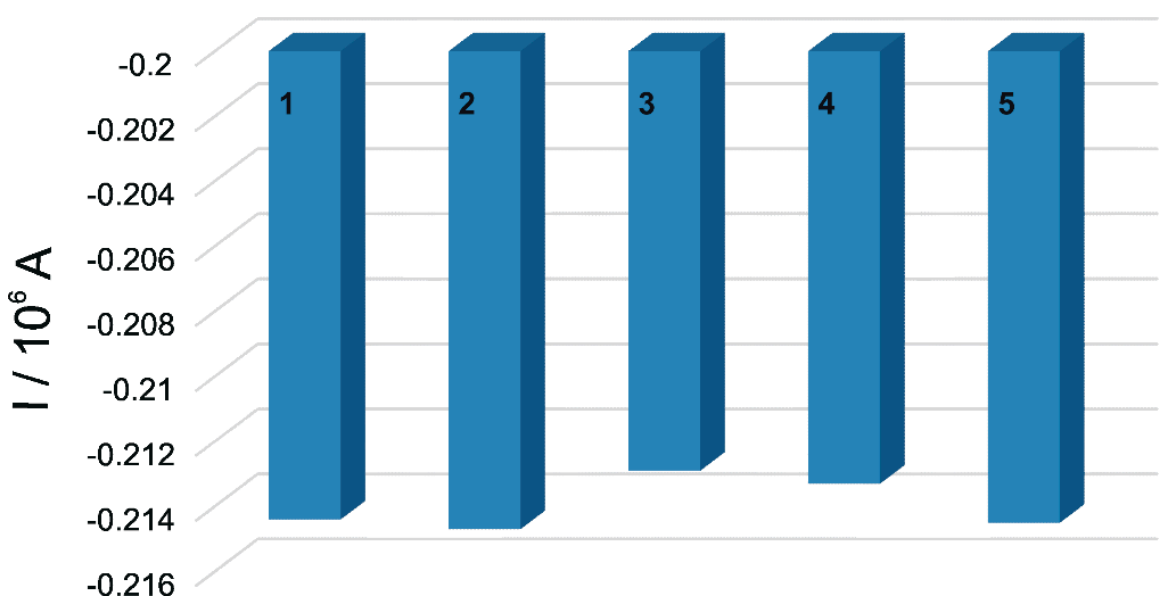

Figure 9. Stability of the responses for $10^{-5} \mathrm{M}$ L-Tyr obtained with five different modified $\mathrm{PPy} / \mathrm{FeCN} / \mathrm{Lacc} / \mathrm{SPCE}$ biosensors (RSD $=0.33 \%$ ).

The substances used in the interference studies were a series of amino acids with similar chemical structure to Tyr, namely, Phe, tryptophan (Trypt), and cysteine. These amino acids were dissolved in a $0.1 \mathrm{M} \mathrm{KCl}$ solution. 
Under the experimental conditions described above, the effects of a series of AAs with similar chemical structure to Tyr, Phe, Trypt, and cysteine were evaluated. Phe, Trypt, and cysteine had low influence on the biosensor response in $0.1 \mathrm{M} \mathrm{KCl}$ solution.

Experimental results (Table 8) show that both substances had almost no interference with the determination of L-Tyr. Therefore, it can be concluded that the proposed method is capable of analyzing L-Tyr in the presence of interfering substances and consequently can be considered specific. The average signal change was found to be $0.42 \%$ for the peak potential and $1.64 \%$ for the current.

Table 8. Interference studies on the voltammetric response of $10^{-5} \mathrm{M}$ L-Tyr at PPy/FeCN/ Lacc/SPCE.

\begin{tabular}{|c|c|c|c|c|c|c|}
\hline $\begin{array}{c}\text { L-Tyr }\left(10^{-5} \mathrm{M}\right)+ \\
\text { Interfering Species } \\
\left(10^{-5} \mathrm{M}\right)\end{array}$ & $\begin{array}{c}\text { Observed } \\
\text { Potential (V) }\end{array}$ & $\begin{array}{c}\text { Potential } \\
\text { Change (\%) }\end{array}$ & $\begin{array}{c}\text { Average Potential } \\
\text { Change }(\%)\end{array}$ & $\begin{array}{c}\text { Observed } \\
\text { Current }\left(10^{6} \mathrm{~A}\right)\end{array}$ & $\begin{array}{c}\text { Current } \\
\text { Change }(\%)\end{array}$ & $\begin{array}{l}\text { Average Current } \\
\text { Change (\%) }\end{array}$ \\
\hline L-Tyr & -0.7444 & - & \multirow{4}{*}{0.42} & -0.2144 & - & \multirow{4}{*}{1.64} \\
\hline L-Tyr + Phe & -0.7419 & 0.33 & & -0.2119 & 1.66 & \\
\hline L-Tyr + Trypt & -0.7403 & 0.55 & & -0.2103 & 1.91 & \\
\hline L-Tyr + Cysteine & -0.7415 & 0.38 & & -0.2115 & 1.35 & \\
\hline
\end{tabular}

\section{Discussion}

Comparing the values obtained by the two devices in terms of both linearity range and detection limit, it is evident that the enzyme sensor showed increased performance, thus demonstrating the importance of the enzyme imprinted on the surface of the working electrode, which makes it more sensitive, as well as the favorable interaction of the Lacc enzyme with tyrosine.

Table 9 shows the performance of some biosensors used for the detection of Tyr by electrochemical methods, the enzymes used for electrode modification, and the samples on which the enzyme sensors were tested. The use of the Lacc enzyme was identified in only one scientific study, thus highlighting the necessity and effectiveness of the new device developed, but no study on the detection of tyrosine in pharmaceutical products has been conducted so far, which means our new device finds its usefulness and applicability in the quality control of such products.

Table 9. Detection method, linearity range, and limit of detection of the biosensors developed for Tyr detection.

\begin{tabular}{|c|c|c|c|c|c|c|c|}
\hline Nr. Crt. & Electrode Material & Enzyme & Real Samples & Detection Method & Linear Range (M) & LOD (M) & Ref. \\
\hline 1 & $\begin{array}{c}\text { Tyrosine hydroxylase onto } \\
\text { palladium-platinum bimetallic } \\
\text { alloy nanoparticles/chitosan-1- } \\
\text { ethyl-3-methylimidazoliurn } \\
\text { bis(trifluoromethylsulfonyl) } \\
\text { imide/graphene-multiwalled } \\
\text { carbon nanotubes-IL/glassy } \\
\text { carbon electrode } \\
\text { (TyrH/PdPt NPs/Ch-IL/Gr- } \\
\text { MWCNTsIL/GCE) }\end{array}$ & $\begin{array}{c}\text { Tyrosine } \\
\text { hydroxylase }\end{array}$ & Food & CV, DPV & $\begin{array}{c}0.01 \times 10^{-9}- \\
8.0 \times 10^{-9} \text { and } \\
8.0 \times 10^{-9}- \\
160.0 \times 10^{-9}\end{array}$ & $0.009 \times 10^{-9}$ & {$[41]$} \\
\hline 2 & $\begin{array}{c}\text { Banana peel tissue } \\
\text { tyrosinase/3-mercaptopropyl } \\
\text { trimethoxysilane-functionalized } \\
\text { silica nanoparticle } \\
\text { (B.P.Tyr/M/SN-MPT) }\end{array}$ & Tyrosinase & $\begin{array}{c}\text { Banana } \\
\text { peel tissue } \\
\text { (Musa Cavendish) }\end{array}$ & CV, DPV & $5 \times 10^{-8}-6 \times 10^{-4}$ & $2 \times 10^{-8}$ & {$[42]$} \\
\hline 3 & $\begin{array}{l}\text { Hemin-modified graphene } \\
\text { nanosheet electrode } \\
\text { (HGN/GCE) }\end{array}$ & Hemin & Tyrosine & $\mathrm{CV}$ & $5 \times 10^{-7}-2 \times 10^{-5}$ & $7.5 \times 10^{-8}$ & {$[43]$} \\
\hline
\end{tabular}


Table 9. Cont.

\begin{tabular}{|c|c|c|c|c|c|c|c|}
\hline Nr. Crt. & Electrode Material & Enzyme & Real Samples & Detection Method & Linear Range (M) & LOD (M) & Ref. \\
\hline 4 & $\begin{array}{l}\text { Glassy carbon electrode with } \\
\text { tyrosine hydroxylase and } \\
\text { reduced graphene oxide } \\
\text { (rGO/TyrHAS/GCE) }\end{array}$ & $\begin{array}{c}\text { Tyrosine } \\
\text { hydroxylase }\end{array}$ & Food & $\mathrm{CV}$ & $\begin{array}{c}1 \times 10^{-12} \\
3.45 \times 10^{-7}\end{array}$ & $7 \times 10^{-11}$ & {$[44]$} \\
\hline 5 & $\begin{array}{c}\text { Tyrosinase } \\
\text { enzyme/multi-walled carbon } \\
\text { nanotubes/polysulfone/glassy } \\
\text { carbon electrode } \\
\text { (TyOx/MWCNT/PSF/GCE) }\end{array}$ & Tyrosinase & Tyrosine & $\mathrm{CV}$ & $\begin{array}{l}1.96 \times 10^{-6}- \\
3.94 \times 10^{-4}\end{array}$ & $3 \times 10^{-10}$ & {$[45]$} \\
\hline 6 & $\begin{array}{l}\text { Organic electrochemical } \\
\text { transistor (OECT) by } \\
\text { functionalizing a single cotton } \\
\text { yarn with semiconducting } \\
\text { PEDOT-modified cotton fiber }\end{array}$ & $\begin{array}{c}\text { Fungal } \\
\text { laccase } \\
\text { POXA1b }\end{array}$ & Textile fiber & UV-VIS, CV & $10^{-8}$ and $10^{-2}$ & $10^{-8}$ & {$[46]$} \\
\hline
\end{tabular}

The biosensor proposed in this study demonstrated increased sensitivity and acceptable performance due to modification with FeCN-doped PPy, also indicating that immobilization of the Lacc enzyme could help to increase the performance of the biosensor for L-Tyr detection.

\section{Conclusions}

In this study, a new biosensor was developed by immobilizing the laccase enzyme on the surface of an electrode modified with a conductive material with excellent properties, PPy polymer doped with $\mathrm{FeCN}$ anion, by chronoamperometry. Characterization of the modified electrode was performed by voltammetric techniques and FT-IR spectroscopy, and the results obtained demonstrated the increased selectivity of the biosensor for the quantitative determination of Tyr compared to those obtained by the unmodified electrode with the Lacc enzyme. In addition, Lacc and CP demonstrated biocompatibility, superior mechanical properties, and a high surface-to-volume ratio for the biosensor. The concentration range in which PPy/FeCN/Lacc/SPCE was tested was in the range of $0.2-6 \times 10^{-6} \mathrm{M}$ and the detection limit obtained was $2.29 \times 10^{-8} \mathrm{M}$, a low value compared to the non-enzymatic sensor and other devices reported in the literature. Moreover, this new biosensor demonstrated good stability for one week and acceptable recoveries when tested on real samples, i.e., pharmaceuticals with different Tyr concentrations. The development of this biosensor can prove effective in controlling the quality of pharmaceutical products containing L-Tyr and is a challenge for future research, in the sense of developing a biosensor to detect the level of L-Tyr in food and biological fluids from birth, as such a device can help prevent many diseases.

Author Contributions: Conceptualization, C.A. and A.D.; methodology, C.A.; validation, C.A. and A.D.; formal analysis, A.D.; investigation, C.A. and A.D.; data curation, C.A. and A.D.; writing-original draft preparation, A.D.; writing-review and editing, C.A.; supervision, C.A. All authors have read and agreed to the published version of the manuscript.

Funding: The contribution of the author Ancuta Dinu was supported by the project ANTREPRENORDOC in the framework of Human Resources Development Operational Programme 2014-2020, financed by the European Social Fund under contract number 36355/23.05.2019 HRD OP/380/6/13SMIS Code: 123847.

Institutional Review Board Statement: Not applicable.

Informed Consent Statement: Not applicable.

Data Availability Statement: The authors confirm that the data supporting the findings of this study are available within the article. 
Conflicts of Interest: The authors declare no conflict of interest. The funders had no role in the design of the study; in the collection, analyses, or interpretation of data; in the writing of the manuscript, or in the decision to publish the results.

\section{References}

1. Stoikov, D.; Ivanov, A.; Shurpik, D.; Stoikov, I.; Evtugyn, G. Flow-Through Electrochemical Biosensor with a Replaceable Enzyme Reactor and Screen-Printed Electrode for the Determination of Uric Acid and Tyrosine. Anal. Lett. 2021, 1-15. [CrossRef]

2. Dinu, A.; Apetrei, C. Development of a Novel Sensor Based on Polypyrrole Doped with Potassium Hexacyanoferrate (II) for Detection of L-Tryptophan in Pharmaceutics. Inventions 2021, 6, 56. [CrossRef]

3. Singh, A.; Sharma, A.; Ahmed, A.; Sundramoorthy, A.K.; Furukawa, H.; Arya, S.; Khosla, A. Recent Advances in Electrochemical Biosensors: Applications, Challenges, and Future Scope. Biosensors 2021, 11, 336. [CrossRef] [PubMed]

4. Karunakaran, C.; Karthikeyan, M.; Kumar, M.D.; Kaniraja, G.; Bhargava, K. Electrochemical Biosensors for Point of Care Applications. Def. Sci. J. 2020, 70, 549-556. [CrossRef]

5. Han, A. Effects of Mindfulness-Based Interventions on Depressive Symptoms, Anxiety, Stress, and Quality of Life in Family Caregivers of Persons Living with Dementia: A Systematic Review and Meta-Analysis. Res. Aging 2021, 016402752110434. [CrossRef] [PubMed]

6. Marr, C.; Sauerland, M.; Otgaar, H.; Quaedflieg, C.W.E.M.; Hope, L. The Effects of Acute Stress on Eyewitness Memory: An Integrative Review for Eyewitness Researchers. Memory 2021, 29, 1091-1100. [CrossRef] [PubMed]

7. Dinu, A.; Apetrei, C. A Review on Electrochemical Sensors and Biosensors Used in Phenylalanine Electroanalysis. Sensors 2020, 20, 2496. [CrossRef]

8. Seim, K.L.; Obermeyer, A.C.; Francis, M.B. Oxidative Modification of Native Protein Residues Using Cerium(IV) Ammonium Nitrate. J. Am. Chem. Soc. 2011, 133, 16970-16976. [CrossRef]

9. Teke Kisa, P.; Eroglu Erkmen, S.; Bahceci, H.; Arslan Gulten, Z.; Aydogan, A.; Karalar Pekuz, O.K.; Yuce Inel, T.; Ozturk, T.; Uysal, S.; Arslan, N. Efficacy of Phenylalanine- and Tyrosine-Restricted Diet in Alkaptonuria Patients on Nitisinone Treatment: Case Series and Review of Literature. Ann. Nutr. Metab. 2021, 1-13. [CrossRef]

10. Negut, C.C.; Stefan-van Staden, R.-I. Review-Recent Trends in Supramolecular Recognition of Dopamine, Tyrosine, and Tryptophan, Using Electrochemical Sensors. J. Electrochem. Soc. 2021, 168, 067517. [CrossRef]

11. Alagawany, M.; Elnesr, S.S.; Farag, M.R.; Tiwari, R.; Yatoo, M.I.; Karthik, K.; Michalak, I.; Dhama, K. Nutritional Significance of Amino Acids, Vitamins and Minerals as Nutraceuticals in Poultry Production and Health-A Comprehensive Review. Vet. Q. 2021, 41, 1-29. [CrossRef]

12. Zil’berg, R.A.; Maistrenko, V.N.; Kabirova, L.R.; Gus'kov, V.Y.; Khamitov, E.M.; Dubrovskii, D.I. A Chiral Voltammetric Sensor Based on a Paste Electrode Modified by Cyanuric Acid for the Recognition and Determination of Tyrosine Enantiomers. J. Anal. Chem. 2020, 75, 101-110. [CrossRef]

13. Pietz, J.; Landwehr, R.; Kutscha, A.; Schmidt, H.; de Sonneville, L.; Trefz, F.K. Effect of High-Dose Tyrosine Supplementation on Brain Function in Adults with Phenylketonuria. J. Pediatr. 1995, 127, 936-943. [CrossRef]

14. Gelenberg, A.J.; Wojcik, J.D.; Growdon, J.; Sved, A.; Wurtman, R. Tyrosine for the Treatment of Depression. Am. J. Psychiatry 1980, 137, 622-623. [CrossRef]

15. Feng, C.-W.; Chen, N.-F.; Chan, T.-F.; Chen, W.-F. Therapeutic Role of Protein Tyrosine Phosphatase 1B in Parkinson's Disease via Antineuroinflammation and Neuroprotection In Vitro and In Vivo. Parkinson's Dis. 2020, 2020, 8814236. [CrossRef] [PubMed]

16. Eastman, J.; Sherwin, J.; Wong, R.; Liao, C.; Currier, R.; Lorey, F.; Cunningham, G. Use of the Phenylalanine: Tyrosine Ratio to Test Newborns for Phenylketonuria in a Large Public Health Screening Programme. J. Med. Screen. 2000, 7, 131-135. [CrossRef]

17. Dinu, A.; Apetrei, C. Voltammetric Determination of Phenylalanine Using Chemically Modified Screen-Printed Based Sensors. Chemosensors 2020, 8, 113. [CrossRef]

18. Bilandžija, H.; Ma, L.; Parkhurst, A.; Jeffery, W.R. A Potential Benefit of Albinism in Astyanax Cavefish: Downregulation of the Oca2 Gene Increases Tyrosine and Catecholamine Levels as an Alternative to Melanin Synthesis. PLoS ONE 2013, 8, e80823. [CrossRef]

19. Hughes, J.H.; Wilson, P.J.M.; Sutherland, H.; Judd, S.; Hughes, A.T.; Milan, A.M.; Jarvis, J.C.; Bou-Gharios, G.; Ranganath, L.R.; Gallagher, J.A. Dietary Restriction of Tyrosine and Phenylalanine Lowers Tyrosinemia Associated with Nitisinone Therapy of Alkaptonuria. J. Inherit. Metab. Dis. 2020, 43, 259-268. [CrossRef]

20. Dinu, A.; Apetrei, C. Development of Polypyrrole Modified Screen-Printed Carbon Electrode Based Sensors for Determination of L-Tyrosine in Pharmaceutical Products. IJMS 2021, 22, 7528. [CrossRef] [PubMed]

21. Jalil Abosadeh, D.; Kashanian, S.; Nazari, M.; Parnianchi, F. Fabrication of a Novel Phenolic Compound Biosensor Using Laccase Enzyme and Metal-Organic Coordination Polymers. Anal. Bioanal. Chem. Res. 2021, 8, 467-480. [CrossRef]

22. Li, M.; Liu, L.; Kermasha, S.; Karboune, S. Laccase-Catalyzed Oxidative Cross-Linking of Tyrosine and Potato Patatin- and Lysozyme-Derived Peptides: Molecular and Kinetic Study. Enzym. Microb. Technol. 2021, 143, 109694. [CrossRef] [PubMed]

23. Li, S.; Xing, M.; Wang, H.; Zhang, L.; Zhong, Y.; Chen, L. Determination of Tryptophan and Tyrosine by Chemiluminescence Based on a Luminol-N-Bromosuccinimide-ZnS Quantum Dots System. RSC Adv. 2015, 5, 59286-59291. [CrossRef]

24. Deng, C.; Deng, Y.; Wang, B.; Yang, X. Gas Chromatography-Mass Spectrometry Method for Determination of Phenylalanine and Tyrosine in Neonatal Blood Spots. J. Chromatogr. B 2002, 780, 407-413. [CrossRef] 
25. Rigobello-Masini, M.; Masini, J.C. Sequential Injection Chromatography for Fluorimetric Determination of Intracellular Amino Acids in Marine Microalgae. In Amino Acid Analysis; Springer: Berlin/Heidelberg, Germany, 2012; pp. $305-315$.

26. Peat, J.; Garg, U. Determination of Phenylalanine and Tyrosine by High Performance Liquid Chromatography-Tandem Mass Spectrometry. In Clinical Applications of Mass Spectrometry in Biomolecular Analysis; Springer: Berlin/Heidelberg, Germany, 2016; pp. 219-225.

27. Mo, X.; Li, Y.; Tang, A.; Ren, Y. Simultaneous Determination of Phenylalanine and Tyrosine in Peripheral Capillary Blood by HPLC with Ultraviolet Detection. Clin. Biochem. 2013, 46, 1074-1078. [CrossRef]

28. Zhang, J.; Li, R.Q. Electrochemical Determination of Tyrosine and Nitrite Using CS/CMWNTs/GCE-Modified Electrode. Int. J. Electrochem. Sci. 2018, 13, 3527-3534. [CrossRef]

29. D'Souza, E.S.; Manjunatha, J.G.; Chenthatti, R.; Tigari, G.; Ravishankar, D.K. Rapid Electrochemical Monitoring of Tyrosine by Poly (Riboflavin) Modified Carbon Nanotube Paste Electrode as a Sensitive Sensor and Its Applications in Pharmaceutical Samples. Biointerface Res. Appl. Chem. 2021, 11, 14661-14672. [CrossRef]

30. Taei, M.; Ramazani, G. Simultaneous Determination of Norepinephrine, Acetaminophen and Tyrosine by Differential Pulse Voltammetry Using Au-Nanoparticles/Poly(2-Amino-2-Hydroxymethyl-Propane-1,3-Diol) Film Modified Glassy Carbon Electrode. Colloids Surf. B Biointerfaces 2014, 123, 23-32. [CrossRef]

31. Kavitha, C.; Bramhaiah, K.; John, N.S. Low-Cost Electrochemical Detection of L-Tyrosine Using an RGO-Cu Modified Pencil Graphite Electrode and Its Surface Orientation on a Ag Electrode Using an Ex Situ Spectroelectrochemical Method. RSC Adv. 2020, 10, 22871-22880. [CrossRef]

32. Kerman, K.; Kraatz, H.-B. Electrochemical Detection of Protein Tyrosine Kinase-Catalysed Phosphorylation Using Gold Nanoparticles. Biosens. Bioelectron. 2009, 24, 1484-1489. [CrossRef]

33. Liu, M.; Lao, J.; Wang, H.; Xu, Z.; Li, J.; Wen, L.; Yin, Z.; Luo, C.; Peng, H. Electrochemical Determination of Tyrosine Using Graphene and Gold Nanoparticle Composite Modified Glassy Carbon Electrode. Russ. J. Electrochem. 2021, 57, 41-50. [CrossRef]

34. Feng, J.; Deng, P.; Xiao, J.; Li, J.; Tian, Y.; Wu, Y.; Liu, J.; Li, G.; He, Q. New Voltammetric Method for Determination of Tyrosine in Foodstuffs Using an Oxygen-Functionalized Multi-Walled Carbon Nanotubes Modified Acetylene Black Paste Electrode. J. Food Compos. Anal. 2021, 96, 103708. [CrossRef]

35. Alam, M.M.; Uddin, M.T.; Asiri, A.M.; Rahman, M.M.; Islam, M.A. Detection of L-Tyrosine by Electrochemical Method Based on Binary Mixed CdO/SnO2 Nanoparticles. Measurement 2020, 163, 107990. [CrossRef]

36. Xu, R.; Zhou, Q.; Li, F.; Zhang, B. Laccase Immobilization on Chitosan/Poly(Vinyl Alcohol) Composite Nanofibrous Membranes for 2,4-Dichlorophenol Removal. Chem. Eng. J. 2013, 222, 321-329. [CrossRef]

37. Haghighi, M.; Shahlaei, M.; Irandoust, M.; Hassanpour, A. New and Sensitive Sensor for Voltammetry Determination of Methamphetamine in Biological Samples. J. Mater. Sci. Mater. Electron. 2020, 31, 10989-11000. [CrossRef]

38. Abdi, Z.; Vandichel, M.; Sologubenko, A.S.; Willinger, M.-G.; Shen, J.-R.; Allakhverdiev, S.I.; Najafpour, M.M. The Importance of Identifying the True Catalyst When Using Randles-Sevcik Equation to Calculate Turnover Frequency. Int. J. Hydrog. Energy 2021, 46, 37774-37781. [CrossRef]

39. Apetrei, C. Novel Method Based on Polypyrrole-modified Sensors and Emulsions for the Evaluation of Bitterness in Extra Virgin Olive Oils. Food Res. Int. 2012, 48, 673-680. [CrossRef]

40. Liu, J.; Niu, J.; Yin, L.; Jiang, F. In Situ Encapsulation of Laccase in Nanofibers by Electrospinning for Development of Enzyme Biosensors for Chlorophenol Monitoring. Analyst 2011, 136, 4802. [CrossRef] [PubMed]

41. Varmira, K.; Mohammadi, G.; Mahmoudi, M.; Khodarahmi, R.; Rashidi, K.; Hedayati, M.; Goicoechea, H.C.; Jalalvand, A.R. Fabrication of a Novel Enzymatic Electrochemical Biosensor for Determination of Tyrosine in Some Food Samples. Talanta 2018, 183, 1-10. [CrossRef] [PubMed]

42. Rahimi-Mohseni, M.; Raoof, J.B.; Ojani, R.; Aghajanzadeh, T.A.; Bagheri Hashkavayi, A. Development of a New Paper Based Nano-Biosensor Using the Co-Catalytic Effect of Tyrosinase from Banana Peel Tissue (Musa Cavendish) and Functionalized Silica Nanoparticles for Voltammetric Determination of 1-Tyrosine. Int. J. Biol. Macromol. 2018, 113, 648-654. [CrossRef]

43. Wei, J.; Qiu, J.; Li, L.; Ren, L.; Zhang, X.; Chaudhuri, J.; Wang, S. A Reduced Graphene Oxide Based Electrochemical Biosensor for Tyrosine Detection. Nanotechnology 2012, 23, 335707. [CrossRef] [PubMed]

44. Moghadam, F.H.; Taher, M.A. Enzymatic Sensing of Tyrosine in Egg and Cheese Samples Using Electrochemical Sensor Amplified with Reduced Graphene Oxide. Food Meas. 2021, 15, 5707-5712. [CrossRef]

45. Phelane, L.; Gouveia-Caridade, C.; Barsan, M.M.; Baker, P.G.L.; Brett, C.M.A.; Iwuoha, E.I. Electrochemical Determination of Tyrosine Using a Novel Tyrosinase Multi-Walled Carbon Nanotube (MWCNT) Polysulfone Modified Glassy Carbon Electrode (GCE). Anal. Lett. 2020, 53, 308-321. [CrossRef]

46. Battista, E.; Lettera, V.; Villani, M.; Calestani, D.; Gentile, F.; Netti, P.A.; Iannotta, S.; Zappettini, A.; Coppedè, N. Enzymatic Sensing with Laccase-Functionalized Textile Organic Biosensors. Org. Electron. 2017, 40, 51-57. [CrossRef] 